\title{
The Impact of Succession Planning on Product and Service Innovation at Family Businesses in Yemen
}

\author{
Tariq Ahmed Alradhi ${ }^{1}$, Mohammed Saleh Al-Abed ${ }^{2}$, Ahmed Ahmed Alkherbi ${ }^{3}$ \\ ${ }^{1}$ Lebanese International University, Sana'a, Yemen \\ ${ }^{2}$ Impact Research Center, Sana'a, Yemen \\ ${ }^{3}$ Sana'a University, Sana'a, Yemen \\ Correspondence: Tariq Ahmed Alradhi, Lebanese International University, Sana'a, Yemen. E-mail: \\ alradhi.tariq@gmail.com
}

Received: September 29, 2020 Accepted: January 3, 2020

Online Published: January 5, 2021

doi:10.48110/joi.v1i1.7

URL: https://doi.org/10.48110/joi.v1i1.7

\begin{abstract}
As increasing numbers of family businesses are emerging, the marketplace is in danger of becoming saturated with products that end users do not understand while competition between businesses becomes stiffer. For businesses that operate in a saturated space to access new opportunities, they need to continually invest in the development of new products and services via a process of creativity and innovation. However, in the contemporary business landscape, innovation has extended beyond being a means of gaining a competitive advantage to being a necessity. To achieve this objective, family firms need to develop an understanding of the factors that influence innovation in order to promote, preserve, and boost innovative practices. This research investigated the impact of succession planning on product and service innovation in Yemeni family businesses. Quantitative approach was employed for the purpose of answering the research questions and testing the underlying hypotheses. A survey questionnaire was utilized as the main instrument to gather the required data from the owners of family firms and organizations that the Yemen Tax Authority has classified as top taxpayers. The sample size consisted of 120 family businesses whose headquarters were located in Sana'a City, Republic of Yemen. Only 116 questionnaires were completed with no invalid data, representing a high response rate of $97 \%$. The results show significant relationships between succession planning and its four dimensions; successor selection and training, post-succession business strategy, post-succession role of incumbent, dissemination of the succession decision with product and service innovation. In addition, the results of Regression analysis reveal that succession planning as the whole independent variable has a significant impact on innovation. Furthermore, results show that the four dimensions of succession planning; successor selection and training, post-succession business strategy, post-succession role of incumbent, and dissemination of the succession decision have a significant impact on product and service innovation. These results provide recommendations to the family business owners, at that they should establish strong and vested plans for succession. They should pay attention to the quality of training that is offered to potential successors. Family businesses should build and rely on "family constitution", which is considered as an important document that includes a definition of the basic values, vision, and general objectives of the company.
\end{abstract}

Keywords: Succession Planning, Successor, Post-succession, Business Strategy, Product and Service Innovation, Yemen, Family Business

\section{Introduction}

The perception that innovation represents an important strategic tool is by no means new. As far back as the 1930s, Schumpeter (1934) described how innovation represents a valuable mechanism by which companies can set themselves apart from their competitors. Family businesses need to invest significantly in R\&D activities to adequately innovate and survive over a long-term basis. Roberts and Amit (2003) emphasized the important role that innovation plays in securing a competitive advantage and enhancing profitability. Many additional studies support this view and have concluded that there is a positive relationship between investment in innovation and the performance of an organization (Zahra \& Das, 1993; Calantone, Vickery, \& Dröge, 1995; Han, Kim, \& Srivastava, 1998). Beaver (2002) argued that innovation is imperative to the overall economic development and progress of a country and its ability to be competitive on a global scale. 
Innovation is not only important for large firms, it also plays a major role in the success of SMEs (Jong \& Vermeulen, 2006; Anderson, 2009). Bakar and Ahmad (2010) emphasized that contemporary organizations need to demonstrate the capability to innovate products, services, and business operations to make the most of any opportunities that arise and establish a competitive advantage. It is for this reason that scholars are increasingly showing an interest in the factors that contribute to the development of innovative practices that can establish a competitive advantage in the global marketplace (Zahra, 1993). From the other side, although academics have begun to take more interest in the ways in which family firms can be innovative, this is still an under-researched area (De Massis, Frattini \& Lichtenthaler, 2013). Some researchers (Craig \& Moores, 2006; Bergfeld \& Weber, 2011) have suggested that family businesses are very keen to innovate so that they can survive in the long term.

Stalk and Foley (2012) highlighted how goal achievement, innovation, and productivity are typically directly impacted by family feuds that develop in response to a lack of succession planning in family firms. Business succession within family businesses typically involve transferring responsibility for leadership of the firm across generations, and it often represents a crucial moment in the firm's lifetime (Ganzaroli, Fiscato, \& Pilotti, 2006). Family-run firms frequently place a focus on growth and survival because they ultimately hope to pass the business down through future generations (Kellermanns, Eddleston, Barnett, \& Pearson, 2008). Many family firms continue to exist long after the founders no longer actively manage the business (Poza, 2010). However, changes in management can represent a major period of uncertainty in which conflict can arise, and the performance of the organization suffers. One common cause of problems during the transition period is that different family members may have different opinions about the direction in which they would like the firm to progress, and a lack of consensus can paralyze the firm.

One way in which the issues described above can be avoided is through robust and strategic succession planning. Collins and O'Regan (2011) described how family firms play a fundamental role in a region's economic performance and that businesses of this nature continue to be the most prevalent organizations across the world. In light of their economic importance, more and more researchers have turned their attention to family firms in recent years, and succession planning and long-term survival have become very common themes of contemporary studies. However, previous research that has focused on family firms has failed to consider the relationship between succession planning and innovation as an integrated model. While many studies have focused on succession, they have not explicitly examined succession planning and the impact it has on innovation with regard to the survival of a family firm (Karanja, 2012; Heck, Hoy, Poutziouris \& Steier, 2008). In light of these gaps in knowledge, there is a distinct requirement to better understand the relationship between succession planning and innovation. In this paper, the impact of succession planning on product and service innovation within family businesses in Yemen was examined.

Yemen, as one of the least developing countries, is economically well known for its small size, which includes unregulated enterprises, individual property, family enterprises (usually limited liability companies), mixed companies and government institutions. Few Yemeni companies are in the form of joint stock companies. According to Al-Haddabi (2014), the total number of private companies in Yemen is more than 110,000 companies, which are estimated at $99 \%$ of the total number of operating companies, excluding governmental and public companies. Yemen's private sector employs 80.5 percent of the labor force. According to the Corporate Governance Guide published by the Yemeni Business Club (2010), family firms make a significant contribution to Yemen's economy and are an important source of jobs. Family companies account for more than $95 \%$ of companies in the Arab world, and this percentage may increase in Yemen because of the lack of public shareholding companies because there is no suitable stock trading environment that encourages such entities.

\section{Literature Review}

\subsection{Product and Service Innovation}

According to the Organization for Economic Cooperation and Development (OECD) (1991), innovation was regarded as a process of repetition that commences when a new market or service opportunity is identified, and a technological invention is subsequently created, manufactured, and marketed for commercial gain. A different view was offered by Rogers (1998), who regarded innovation as the creation of value, in which "the creation of abstract knowledge, or invention of new products and processes, is not normally considered innovation until it has been productively incorporated into the enterprise's activities" (p.9).

The ways in which organizations and even countries perform can be heavily influenced by their capacity for innovation (Harris \& Mowery, 1990). The chief virtue of innovation is that innovative companies can swiftly respond to change, offering new products and seeking out new markets, and resisting disruption when the financial and/or business worlds are unstable (Miles \& Snow, 1978). It is generally accepted that firms that wish to remain 
on equal terms with competitors, or develop in the longer term, must be innovative (Hamel, 1998; Roberts, 1998).

Beck, Janssens, Debruyne, and Lommelen, (2011) looked at the extent of a company's success in creating, adoption, and implementation of products, ideas, and processes, measuring the innovation capabilities of a company by these variables, while Rajapathirana and Hui (2017) took four dimensions to assess the innovation activities in insurance companies. These were insurance product innovation, process innovation, marketing innovation and organizational innovation. Škerlavaj, Song, and Lee (2010) looked at a model of innovation and improvement in the lives of Organizational Learning Culture (OLC). They measured innovation in terms of innovation in Product and Service (Technical) Innovation, Process (Administrative) Innovation, and Innovativeness (Innovative Culture). This paper focused only on product and service innovation.

Alegre, Lapiedra and Chiva (2006) define product innovation as "a process that involves the technical design, $\mathrm{R} \& \mathrm{D}$, manufacturing, management and commercial activities involved in the marketing of a new (or improve) product." (p.317). The same process is described by Chaochotechuang $(2016, \mathrm{p} .48)$ as, "The introduction of a good or service that is new or significantly improved with respect to its characteristics or intended uses."

Product and Service Innovation via the foundation of innovative organizations; innovation of this nature is essential for improving overall innovation performance. Products and services innovation is vital for firms, as can be seen in two respects: all companies engage in innovation, and also entrepreneurs recognize that innovation is an essential part of improving business performance: “... we never stop developing a system [the main product of the company]... every new client demands that we update the general concept of the system..." (Melo, 2011).

Companies with ambitions to be benchmarks of quality should always remember their customers and what they need and prefer. Knowing what customers need and prefer is a prerequisite for innovation in terms of products and services. It is essential, given the competitive nature of the business environment, that companies innovate their products and services in order to provide greater customer satisfaction than their competitors.

\subsection{Succession Planning}

Succession planning relates to the theory and practice of organization and involves passing responsibility for the management of an organization from a leader, or a generation of leaders, to the subsequent leadership. Succession encompasses what happens before the handover is made, as well as what happens afterwards (Shepherd \& Zacharakis, 2000). Nyalita $(2015$, p.22) defined succession as “ $\ldots$ a process than of transferring ownership and management control to the successor who is a family member." In terms of family businesses, succession has been defined as everything related to passing control of leadership between family members (Sharma, Chrisman, Pablo, \& Chua, 2001). Expanding on this, succession refers to the transfer, from one generation of either a nuclear or extended family, of control and ownership of all assets of a company to the following generation.

In succession planning, control and management are passed between family members (Sharma, Yetton, \& Crawford, 2009). Family members can be any relation, children, spouses, grandchildren, etc. The majority of SMEs are family businesses and the way in which family succession is handled plays a significant part in whether they develop and survive (Esuha \& Fletcher, 2000). For successful succession planning, the most important management positions must be identified, from the lowest ranks of the company to the highest. It must be very flexible in terms of allowing managers to move laterally within the company. The management skills of individuals will become broader as they move up the organization, and they will shift their focus from the objectives of their department to the objectives of the organization as a whole (Rothwell, 2010).

For a business to have continuity, succession planning is essential. This can be seen in the accounting concept of the "going concern," which requires an organization to remain in business for an indeterminate length of time in the future (Wood, 1999). If a business is to achieve the status of going concern, succession planning must be a major focus. The ultimate test of a family business is its handling of succession. If a business passes from the control of a single person to a family, all interested parties will be unified by the need for continuity. If the new generation inherits the business in decent order and in profit, they will be inspired to continue (Gersick, 1997). In a survey of Canadian family business entrepreneurs, Chua, Chrisman, and Sharma (2003) found that their primary concern was succession.

If a succession plan is carefully designed and managed, it will be able to stand the test of time as it will be designed to react to changes in strategy and mission for the business (Leibman, Bruer \& Maki, 1996; Rioux \& Berthal, 1999). Effective succession planning will assist in identifying who the key workers are in an organization and also to identify the needs of the organization in terms of training programs, skills, and work experience; this information is critical in terms of business development.

In the studies, which do exist, innovation has been found to have a negative correlation with succession in family businesses (Grundström, Öberg, \& Rönnbäck, 2012; Ganzaroli, et al., 2006). Grundström et al. (2012) undertook 
10 case studies and compared the ways in which company innovation was affected depending on whether a succession came from within a family or from an external party. This study revealed that when a family SME as a family member as the successor, the company will make very little effort to be truly innovative by searching for new ideas or adapting existing ones, but will persist with small-scale innovation that will not be at the same level intensity as companies that have been subject to external takeover.

The second generation of family firms tend to have lower levels of R\&D; Block (2012) suggested that this is due to successor complacency - as they have not had to make efforts to secure their position, simply inheriting it, the chief ambition is for the firm simply to survive, rather than to be successful in the long term by development and innovation.

Meneses, Coutinho, and Carlos Pinho (2014) undertook a case study examining the succession in six family SMEs, with reference to the ways in which success in and internationalization were precursors to innovation. They found that internationalization was not greatly affected by the age of the successor, the education, their experience all foreign language expertise. It was found, however, that internationalization was notably impacted by successors having a desire for innovation, an international vision, and being proactive. Accordingly, this study developed the following hypothesis.

\section{H1: Family succession planning has a significant impact on Product and Service Innovation.}

The ways in which factors related to the family influence the succession process in family-owned SMEs was investigated by Venter and Boshoff (2005). Two dimensions were used to measure the succession process, namely satisfaction with the process and continued profitability of the business. Van der Merwe (2010) examined factors influencing the roles played by senior generations of a family, including how competent the prospective successor was perceived to be, how much the senior generation participated in management, how well the prospective successor was prepared, and how well the potential of the next generation was utilized.

Sharma, Chrisman and Chua (2003) constructed a model in which the dependent variables were for activities related to succession planning, and the independent variables were four attributes of family firms. The dependent variables were successor selection and training, developing a post-succession strategy for the business, defining the post-succession role of the departing incumbent, and communicating the decision to key stakeholders. In this paper succession planning was measured by adapting the four dimensions proposed by Sharma, Chrisman and Chua (2003); namely; successor selection and training, post-succession business strategy, post-succession role of incumbent, and dissemination of the succession decision.

\subsubsection{Successor Selection and Training}

The successor in a family business is the member of the family who takes over leadership, management, and eventually ownership, of the company once the founder retires or resigns. "Potential successor" refers to a member of the family who has the required abilities and a desire to assume control of the family business, but has not yet done so, or failed to do so. Although many researchers have studied the part played by the founder of the business in succession processes, and the process itself, the role played by successors has not been studied as deeply. Some research has sought to establish the attributes of a successor that aided successful transitions (Sharma, Chrisman, \& Chua, 1997)

There is an important part to play in the succession process for development and training; the amount of knowledge a successor has acquired, and how far their capabilities have been developed, influence both their ability to take on the leadership role and their credibility in the eyes of others. Ward (1987) revealed that when firms were successful in surviving the succession process, well-trained successors were the most important factor. Morris, Williams, Allen \& Avila (1997) interviewed twenty family members who had taken over the business from the previous generation and found that lack of preparedness from successors was a major factor in the process breaking down. Accordingly, this study developed the following hypothesis.

\section{H1a: Successor selection and training have a significant impact on Product and Service Innovation.}

\subsubsection{Post-Succession Business Strategy}

Business strategy has been defined by Chandler (1962) as the ways in which long-term targets and plans of action developed, as well as how resources are allocated to assist in their achievement. Ansoff (1965) proposed a definition of strategy as being the rules whereby companies make decisions, which were influenced by competitive advantages, growth, and the scope of the product and the market. Miles and Snow (1978) defined business strategies as encompassing all the large and small decisions taken regarding an organization's future. 
As a successor takes over a business, s/he will face an expectation that they will introduce strategies to allow the firm to keep pace with modern business trends and practices, e.g., new technology, whether on the factory floor or on the Internet. A business owner should be closely involved in monitoring the introduction of these strategies, to ensure that they are suitable for the business, making it more efficient without going against the established business philosophy. Accordingly, this study developed the following hypothesis.

\section{H1b: Post-succession business strategy has a significant impact on Product and Service Innovation.}

\subsubsection{Post-Succession Role of Incumbent}

Kelly, Athanassiou, and Crittenden (2000) suggested in a similar way that the legacy of the founder of the family business will continue to influence the strategies implemented by managers from following generations, with outcomes that are both positive and negative. Davis and Harveston (1999) examined the impact of generational shadow, but the conclusions as to its impact were mixed.

The founder can improve the chances of a successful succession by inspiring commitment from successors, encouraging their abilities, and committing to succession plans. A founder can also damage the chances of a successful succession, by undermining the successors and refusing to plan a succession; however, successors can mitigate such negativity by showing an increased commitment and competence, even if the founder will not acknowledge it. If we define family businesses as being ones which are determined to remain within the ownership of the family and be led by them, the praise or blame for the success or otherwise of the succession process it is, essentially, down to the successor (Dyck, Mauws, Starke \& Mischke, 2002).

When the successor is another family member, the relationship between the successor and the incumbent is the key influencer of success or otherwise. If the successor is not a relation, there are no particular influential factors on the success or otherwise of the process. The relationship between the incumbent and the success that is the crucial one in terms of post-succession business success (Alwis, 2016). Accordingly, this study developed the following hypothesis.

\section{H1c: Post-succession role of incumbent has a significant impact on Product and Service Innovation.}

\subsubsection{Dissemination of the Succession Decision}

A family business will have better chances of survival if succession planning has been undertaken to guard against the possibility of succession being forced. Dyck et al. (2002) explained that family businesses with proper succession plans, which had been clearly explained to the main stakeholders in the family business, had a greater likelihood of carrying on the family business and making a profit post-succession businesses that had not made any plans.

By employing game theory to analyze the interactions between founders and successors in family business, we can reveal the ways in which inadequate communication between individuals can impact on the harmony of the family during a succession process. Inadequate communications cause disagreements and flashpoints between the founder and the successor; this will gradually militate against family harmony. The findings show that not only does this have damaging psychological effects, but that it will cause positive harm to the process of transition, even when the personnel involved agree on all major issues. Accordingly, this study developed the following hypothesis.

H1d: Dissemination of the succession decision has a significant impact on Product and Service Innovation.

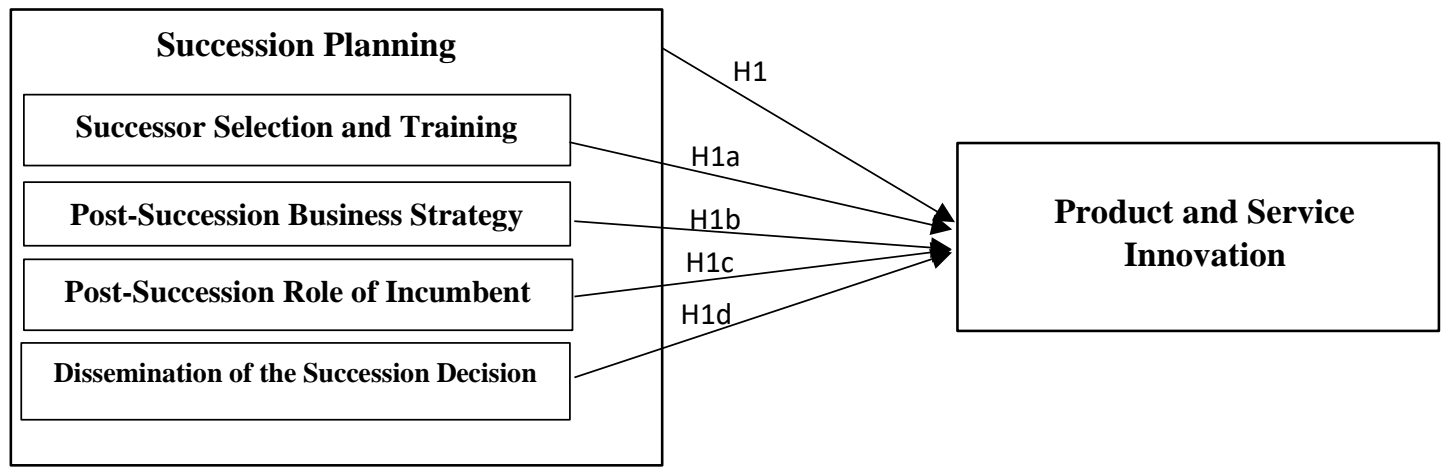

Figure 1. Conceptual Framework 


\section{Methods}

This study employed quantitative approach and it is a hypothesis testing study. Self-administered questionnaires were used in order to collect the required data from the owners of family businesses in the commercial, industrial, and service sectors that are operating in Sana'a, the capital of Yemen. Initially, the study participants were supposed to be selected based on specific statistics about Yemeni companies classified as family companies in the Ministry of Industry and Commerce, the Chamber of Commerce, and the Yemeni Business Club. Unfortunately, those statistics were not available because certain authorities failed to complete the classifications. Thus, a decision was made to use the Yemeni Tax Authority to obtain statistics for the targeted companies, especially those family companies that were classified as senior taxpayers in 2016. The respondents comprised 120 family companies whose headquarters and main offices are mainly in Sana'a. Accordingly, the study population of this research includes all 120 owners of family businesses operating in Sana'a. According to Krejcie and Morgan (1970), 92 of the family businesses was the representative sample size for this study. Due to the small size of the study population and its small limitation, it was decided to distribute the questionnaires to the entire study population (120). Thus, the questionnaires were distributed to those 120 family companies using the convenient sampling method.

This study followed Sharma et al. (2003) by adapting twelve items in order to measure the four dimensions; of succession planning; namely; successor selection and training, post-succession business strategy, post-succession role of the incumbent, and dissemination of the succession decision. In addition, this study adapted nine items from Škerlavaj et al. (2010) in order to measure product and service innovation.

\section{Findings}

In total, 120 questionnaires were distributed. Of these, 116 valid responses were received, representing a relatively high response rate of $97 \%$. The collected data was first screened to ensure that it was clean from any missing, extreme values, and duplicated cases. Following that it was analyzed using SPSS software V.23. Table 1 shows the descriptive statistics of the items used to measure successor selection and training together with the mean and standard deviation. The results indicate that the participants agreed most strongly with Item 3 ("Explicit efforts were made to train potential successors for their future role in the business"), with a mean of 4.41, standard deviation of 0.698 , and percentage of $88.2 \%$ (Strongly Agree). The participants least agreed with Item 2 ("Explicit succession criteria were developed for identifying the best successor"), with a mean of 4.05 , standard deviation of 0.811 , and a percentage of $81 \%$ (Agree). The mean of the successor selection and training dimension was 4.19 , the standard deviation was 0.594 , and the percentage level of agreement was $83.8 \%$ (Agree).

In addition, Table 1 shows the descriptive statistics of the items measured the post-succession business strategy. The results revealed that the participants most strongly agreed with Item 1 ("We had an understanding of what the business strategy would be after leadership was transferred to the successor") and Item 2 ("We had an explicit plan for the business after the transfer of leadership to the business"), which had the same rank (mean of 4.10 and percentage 82\%: Agree, but different standard deviations of 0.917 and 0.795 respectively). The mean of the postsuccession business strategy dimension was 4.10 and the standard deviation was 0.759 with a percentage of $82 \%$ (Agree).

Furthermore, Table 1 shows the descriptive statistics of the items measured the post-succession role of the incumbent. The results indicated that the participants most strongly agreed with Item 2 ("We had an unwritten understanding of my roles and responsibilities after the leadership was passed on to the successor") with a mean of 4.23 , standard deviation of 0.762 , and percentage of $84.6 \%$ (Strongly Agree). The participants least strongly agreed with Item 1 ("We had a formal plan regarding my roles and responsibilities in the business, once the leadership role was passed on to the successor"), with a mean of 4.03 , standard deviation of 0.844 , and percentage of $80.6 \%$ (Agree). The mean of the post-succession role of incumbent dimension was 4.12 , the standard deviation was 0.617 , and the percentage was $82.4 \%$ (Agree).

For the items used to measure the dissemination of the succession decision, the results of the descriptive statistics, as shown in Table 1, indicated that the participants most strongly agreed with Item 1 ("The decision of who the successor would be was clearly communicated to family members active in the business") with a mean of 4.13, standard deviation of 0.808 , and percentage agreement of $82.6 \%$ (Agree). The item that the participants second most strongly agreed with was Item 2 ("The decision of who the successor would be was clearly communicated to the key employees"), which had a mean of 4.05 , standard deviation of 0.832 , and percentage agreement of $81.0 \%$ (Agree). The mean of the dissemination of the succession decision dimension was 4.09 , the standard deviation was 0.736 , and the percentage was $81.8 \%$ (Agree). 
Table 1. Descriptive Statistics of Succession Planning

\begin{tabular}{|c|c|c|c|c|c|c|}
\hline No & Items & Rank & Mean & $\begin{array}{l}\text { Std. } \\
\text { Deviation }\end{array}$ & Percent & $\begin{array}{l}\text { Variable } \\
\text { Interpretation } \\
\end{array}$ \\
\hline \multicolumn{7}{|c|}{ Successor selection and training } \\
\hline \multirow{2}{*}{$\begin{array}{l}1 \\
2\end{array}$} & A list of potential successors was developed & 3 & 4.16 & 0.791 & 83.2 & Agree \\
\hline & $\begin{array}{l}\text { Explicit succession criteria were developed } \\
\text { for identifying the best successor }\end{array}$ & 5 & 4.05 & 0.811 & 81.0 & Agree \\
\hline 3 & $\begin{array}{l}\text { Explicit efforts were made to train potential } \\
\text { successors for their future role in the } \\
\text { business }\end{array}$ & 1 & 4.41 & 0.698 & 88.2 & $\begin{array}{l}\text { Strongly } \\
\text { Agree }\end{array}$ \\
\hline 4 & $\begin{array}{l}\text { Explicit attention was given to familiarize } \\
\text { the potential successors with the business } \\
\text { prior to the succession }\end{array}$ & 2 & 4.30 & 0.771 & 86.0 & $\begin{array}{l}\text { Strongly } \\
\text { Agree }\end{array}$ \\
\hline \multirow[t]{2}{*}{5} & $\begin{array}{l}\text { Explicit attention was given to familiarize } \\
\text { the potential successors with the employees } \\
\text { of the business prior to the succession }\end{array}$ & 4 & 4.06 & 0.873 & 81.2 & Agree \\
\hline & & & 4.19 & 0.594 & 83.8 & Agree \\
\hline \multicolumn{7}{|c|}{ Post-succession Business Strategy } \\
\hline 1 & $\begin{array}{l}\text { We had an understanding of what the } \\
\text { business strategy would be after leadership } \\
\text { was transferred to the successor }\end{array}$ & 1 & 4.10 & 0.917 & 82.0 & Agree \\
\hline \multirow[t]{2}{*}{2} & $\begin{array}{l}\text { We had an explicit plan for the business } \\
\text { after the transfer of leadership to the } \\
\text { business }\end{array}$ & 1 & 4.10 & 0.795 & 82.0 & Agree \\
\hline & & & 4.10 & 0.759 & 82.0 & Agree \\
\hline \multicolumn{7}{|c|}{ Post-succession Role of Incumbent } \\
\hline 1 & $\begin{array}{l}\text { We had a formal plan regarding my roles } \\
\text { and responsibilities in the business, once the } \\
\text { leadership role was passed on to the } \\
\text { successor }\end{array}$ & 3 & 4.03 & 0.844 & 80.6 & Agree \\
\hline 2 & $\begin{array}{l}\text { We had an unwritten understanding of my } \\
\text { roles and responsibilities after the leadership } \\
\text { was passed on to the successor }\end{array}$ & 1 & 4.23 & 0.762 & 84.6 & $\begin{array}{l}\text { Strongly } \\
\text { Agree }\end{array}$ \\
\hline \multirow[t]{2}{*}{3} & $\begin{array}{l}\text { A financial package was developed for my } \\
\text { retirement }\end{array}$ & 2 & 4.09 & 0.830 & 81.8 & Agree \\
\hline & & & 4.12 & 0.617 & 82.4 & Agree \\
\hline \multicolumn{7}{|c|}{ Dissemination of the Succession Decision } \\
\hline 1 & $\begin{array}{l}\text { The decision of who the successor would be } \\
\text { was clearly communicated to family } \\
\text { members active in the business }\end{array}$ & 1 & 4.13 & 0.808 & 82.6 & Agree \\
\hline \multirow[t]{2}{*}{2} & $\begin{array}{l}\text { The decision of who the successor would be } \\
\text { was clearly communicated to the key }\end{array}$ & 2 & 4.05 & 0.832 & 81.0 & Agree \\
\hline & & & 4.09 & 0.736 & 81.8 & Agree \\
\hline
\end{tabular}

Table 2 presents the descriptive statistics in terms of mean, standard deviation, and percentage in agreement for the items measuring the product and service innovation. The results indicate that the participants most strongly agreed with Item 2 ("Our new products and services are often perceived as very novel by customers") with a mean of 4.42 , standard deviation of 0.793 , and percentage of $88.4 \%$ (Strongly Agree). The participants least strongly agreed with Item 8 ("Our firm manages to deliver special products flexibly according to customers' orders"), with a mean of 4.05 , standard deviation of 0.881 , and percentage level of agreement of $81.0 \%$ (Agree). The mean of the product and service innovation variable was 4.20 and the standard deviation was 0.550 with a percentage agreement of $84 \%$ (Agree). 
Table 2. Descriptive Statistics of Product and Service Innovation

\begin{tabular}{|c|c|c|c|c|c|c|}
\hline No & Items & Rank & Mean & $\begin{array}{l}\text { Std. } \\
\text { Deviation }\end{array}$ & Percent & $\begin{array}{l}\text { Variable } \\
\text { Interpretation }\end{array}$ \\
\hline 1 & $\begin{array}{l}\text { In new product and service } \\
\text { introduction, our company is often } \\
\text { first-to-market }\end{array}$ & 5 & 4.19 & 0.801 & 83.8 & Agree \\
\hline 2 & $\begin{array}{l}\text { Our new products and services are } \\
\text { often perceived as very novel by } \\
\text { customers }\end{array}$ & 1 & 4.42 & 0.793 & 88.4 & Strongly Agree \\
\hline 3 & $\begin{array}{l}\text { New products and services in our } \\
\text { company often take us up against new } \\
\text { competitors }\end{array}$ & 4 & 4.22 & 0.814 & 84.4 & Strongly Agree \\
\hline 4 & $\begin{array}{l}\text { In comparison with competitors, our } \\
\text { company has introduced more } \\
\text { innovative products and services } \\
\text { during past } 5 \text { years }\end{array}$ & 3 & 4.23 & 0.868 & 84.6 & Strongly Agree \\
\hline 5 & $\begin{array}{l}\text { We continually emphasize } \\
\text { development of particular and patent } \\
\text { products }\end{array}$ & 8 & 4.06 & 0.887 & 81.2 & Agree \\
\hline 6 & $\begin{array}{l}\text { We manage to cope with market } \\
\text { demands and develop new products } \\
\text { quickly }\end{array}$ & 7 & 4.09 & 0.884 & 81.8 & Agree \\
\hline 7 & $\begin{array}{l}\text { We continuously modify design of our } \\
\text { products and rapidly enter new } \\
\text { emerging markets }\end{array}$ & 6 & 4.16 & 0.791 & 83.2 & Agree \\
\hline 8 & $\begin{array}{l}\text { Our firm manages to deliver special } \\
\text { products flexibly according to } \\
\text { customers' orders }\end{array}$ & 9 & 4.05 & 0.811 & 81.0 & Agree \\
\hline 9 & $\begin{array}{l}\text { We continuously improve old products } \\
\text { and raise quality of new products }\end{array}$ & 2 & 4.41 & 0.698 & 88.2 & Strongly Agree \\
\hline \multicolumn{3}{|c|}{ Product and Service Innovation } & 4.20 & 0.550 & 84 & Agree \\
\hline
\end{tabular}

In addition, For the purpose of understanding the relationship between succession planning, the independent variable, and product and service innovation, the dependent variable, correlation analysis was performed. The results indicated that there is a significant strong and positive relationship between succession planning and product and service innovation $(\mathrm{r}=0.928, \mathrm{P}=.000<0.01$, 2-tailed). In addition, the results indicated that there is a significant and strong positive relationship between successor selection and training, and product and service innovation ( $\mathrm{r}=0.874, \mathrm{P}=000<0.01,2$-tailed), post-succession business strategy, and product and service innovation $(\mathrm{r}=0.723, \mathrm{P}=.000<0.01$, 2-tailed $)$, post-succession role of incumbent and product and service innovation $(\mathrm{r}=0.822, \mathrm{P}=.000<0.01,2$-tailed $)$, and dissemination of the succession decision and product and service innovation $(\mathrm{r}=0.781, \mathrm{P}=.000<0.01,2$-tailed $)$. Table 3 shows the results of the correlation analysis. 
Table 3. Correlation Analysis

\begin{tabular}{|c|c|c|c|c|c|c|c|}
\hline & & $\begin{array}{l}\text { Succession } \\
\text { Planning }\end{array}$ & $\begin{array}{l}\text { Successor } \\
\text { selection } \\
\text { and } \\
\text { training }\end{array}$ & $\begin{array}{c}\text { Post- } \\
\text { succession } \\
\text { business } \\
\text { strategy }\end{array}$ & $\begin{array}{c}\text { Post- } \\
\text { succession } \\
\text { role of } \\
\text { incumbent }\end{array}$ & $\begin{array}{c}\text { Dissemination } \\
\text { of the } \\
\text { succession } \\
\text { decision }\end{array}$ & $\begin{array}{c}\text { Product } \\
\text { and } \\
\text { Service } \\
\text { Innovation }\end{array}$ \\
\hline \multirow{4}{*}{$\begin{array}{l}\text { Succession } \\
\text { Planning }\end{array}$} & Pearson & 1 & $.934^{* * *}$ & $.797^{* *}$ & $.851^{* * *}$ & $.868^{* *}$ & $.928^{* *}$ \\
\hline & Correlation & & & & & & \\
\hline & $\begin{array}{l}\text { Sig. (2- } \\
\text { tailed) }\end{array}$ & & .000 & .000 & .000 & .000 & .000 \\
\hline & $\mathrm{N}$ & 116 & 116 & 116 & 116 & 116 & 116 \\
\hline \multirow{3}{*}{$\begin{array}{l}\text { Successor } \\
\text { selection and } \\
\text { training }\end{array}$} & Pearson & $.934^{* * *}$ & 1 & $.678^{* *}$ & $.799^{* *}$ & $.746^{* *}$ & $.874^{* *}$ \\
\hline & $\begin{array}{l}\text { Correlation } \\
\text { Sig. (2- } \\
\text { tailed) }\end{array}$ & .000 & & .000 & .000 & .000 & .000 \\
\hline & $\mathrm{N}$ & 116 & 116 & 116 & 116 & 116 & 116 \\
\hline \multirow{3}{*}{$\begin{array}{l}\text { Post- } \\
\text { succession } \\
\text { business } \\
\text { strategy }\end{array}$} & $\begin{array}{l}\text { Pearson } \\
\text { Correlation }\end{array}$ & $.797^{* *}$ & $.678^{* *}$ & 1 & $.490^{* *}$ & $.605^{* *}$ & $.723^{* *}$ \\
\hline & $\begin{array}{l}\text { Sig. (2- } \\
\text { tailed) }\end{array}$ & .000 & .000 & & .000 & .000 & .000 \\
\hline & $\mathrm{N}$ & 116 & 116 & 116 & 116 & 116 & 116 \\
\hline \multirow{3}{*}{$\begin{array}{l}\text { Post- } \\
\text { succession } \\
\text { role of } \\
\text { incumbent }\end{array}$} & $\begin{array}{l}\text { Pearson } \\
\text { Correlation }\end{array}$ & $.851^{* *}$ & $.799^{* *}$ & $.490^{* *}$ & 1 & $.638^{* *}$ & $.822^{* *}$ \\
\hline & $\begin{array}{l}\text { Sig. (2- } \\
\text { tailed) }\end{array}$ & .000 & .000 & .000 & & .000 & .000 \\
\hline & $\mathrm{N}$ & 116 & 116 & 116 & 116 & 116 & 116 \\
\hline \multirow{3}{*}{$\begin{array}{l}\text { Dissemination } \\
\text { of the } \\
\text { succession } \\
\text { decision }\end{array}$} & $\begin{array}{l}\text { Pearson } \\
\text { Correlation }\end{array}$ & $.868^{* *}$ & $.746^{* *}$ & $.605^{* *}$ & $.638^{* *}$ & 1 & $.781^{* * *}$ \\
\hline & $\begin{array}{l}\text { Sig. (2- } \\
\text { tailed) }\end{array}$ & .000 & .000 & .000 & .000 & & .000 \\
\hline & $\mathrm{N}$ & 116 & 116 & 116 & 116 & 116 & 116 \\
\hline \multirow{4}{*}{$\begin{array}{l}\text { Product and } \\
\text { Service } \\
\text { Innovation }\end{array}$} & Pearson & $.928^{* * *}$ & $.874^{* *}$ & $.723^{* *}$ & $.822^{* *}$ & $.781^{* *}$ & 1 \\
\hline & Correlation & & & & & & \\
\hline & $\begin{array}{l}\text { Sig. (2- } \\
\text { tailed) }\end{array}$ & .000 & .000 & .000 & .000 & .000 & \\
\hline & $\mathrm{N}$ & 116 & 116 & 116 & 116 & 116 & 116 \\
\hline
\end{tabular}

**. Correlation is significant at the 0.01 level (2-tailed).

For the purpose of examining H1, which assumes that succession planning as the whole independent variable has a significant impact on product and service innovation, a simple regression was performed. The output of the model summary of the simple regression for forecasting the product and service innovation is shown in Table 4 The results reveal that the $\mathrm{R}^{2}$ was 0.860 , which indicates that succession planning can explain $86 \%$ of variation in the product and service innovation.

Table 4. Model Summary

\begin{tabular}{lllll}
\hline Model & $\mathrm{R}$ & $\mathrm{R}$ Square & Adjusted R Square & Std. Error of the Estimate \\
\hline 1 & $.928^{\mathrm{a}}$ & .860 & .859 & 0.148126 \\
\hline
\end{tabular}

a. Predictors: (Constant), Succession Planning

Table 5 presents the results of the ANOVA analysis. The results reveal that the F proportion was 702.547 and the level of significance of the whole model was below $0.05(\mathrm{p}=.000)$, indicating that the model is accepted.

Table 5. ANOVA a Analysis

\begin{tabular}{lllllll}
\hline Model & & Sum of Squares & Df & Mean Square & F & Sig. \\
\hline 1 & Regression & 15.414814 & 1 & 15.415 & 702.547 & $.000^{\mathrm{b}}$ \\
& Residual & 2.501 & 114 & .022 & & \\
& Total & 17.916 & 115 & & & \\
\hline
\end{tabular}

a. Dependent Variable: Product and Service Innovation

b. Predictors: (Constant), Succession Planning 
Table 6 shows the coefficients of the simple regression. The result of the analysis revealed that succession planning as a whole independent variable had a significant impact on product and service innovation $(\beta=0.978, \mathrm{p}=0.000$ $<0.01$ ), which supports H1.

Table 6. Coefficients of Simple Regression

\begin{tabular}{lllllll}
\hline Model & & \multicolumn{2}{l}{ Unstandardized Coefficients } & $\begin{array}{l}\text { Standardized } \\
\text { Coefficients }\end{array}$ & T & Sig. \\
\cline { 3 - 6 } & & B & Std. Error & Beta & \\
\hline \multirow{2}{*}{1} & (Constant) & .042 & .143 & & .296 & .768 \\
& Succession Planning & .978 & .037 & .928 & 26.506 & .000 \\
\hline
\end{tabular}

a. Dependent Variable: Product and Service Innovation

In addition, a multiple regression analysis was performed to examine the impact that the four dimensions of succession planning - successor selection and training, post-succession business strategy, post-succession role of incumbent, and dissemination of the succession decision - on the dependent variable (product and service innovation). The summary of the multiple regression for predicting the product and service innovation is shown in Table 7. The results show that the $\mathrm{R}^{2}$ value was 0.865 , which indicates that the four dimensions can explain $86.5 \%$ of the product and service innovation.

Table7. Model Summary

\begin{tabular}{|c|c|c|c|c|}
\hline Model & $\mathrm{R}$ & R Square & Adjusted R Square & $\begin{array}{l}\text { Std. Error of the } \\
\text { Estimate }\end{array}$ \\
\hline 1 & $.930^{\mathrm{a}}$ & .865 & .860 & 14761 \\
\hline
\end{tabular}

Predictors: (Constant), Successor selection and training, Post-succession business strategy, Post-succession role of incumbent, Dissemination of the succession decision

Table 8 presents the result of the ANOVA analysis. The F proportion was 177.819 and the level of significance of the whole model was below $0.05(\mathrm{p}=.000)$ indicating that the model is accepted.

Table8. ANOVA a Analysis

\begin{tabular}{|c|c|c|c|c|c|}
\hline Model & Sum of Squares & Df & Mean Square & $\mathrm{F}$ & Sig. \\
\hline 1 Regression & 15.498 & 4 & 3.874 & 177.819 & $.000^{\mathrm{b}}$ \\
\hline Residual & 2.419 & 111 & .022 & & \\
\hline Total & 17.916 & 115 & & & \\
\hline
\end{tabular}

a. Dependent Variable: Product and Service Innovation

b. Predictors: (Constant), Successor selection and training, Post-succession business strategy, Post-succession role of incumbent, Dissemination of the succession decision

Table 9 shows the coefficients of the multiple regression. The result of the analysis revealed that successor selection and training have a significant impact on product and service innovation $(\beta=0.252, \mathrm{~T}=3.745, \mathrm{p}=0.000$ $<0.05$ ), which supports H1a. In addition, the post-succession business strategy has a significant impact on product and service innovation $(\beta=0.226, \mathrm{~T}=4.851, \mathrm{p}=0.000<0.05)$, supporting $\mathrm{H} 1 \mathrm{~b}$.

Furthermore, the post-succession role of incumbent has a significant impact on product and service innovation $(\beta=0.316, T=5.996, p=0.000<0.05)$, which supports H1c.

Finally, the dissemination of the succession decision has a significant impact on product and service innovation $(\beta=0.183, \mathrm{~T}=3.808, \mathrm{p}=0.000<0.05)$, which support H1d.

Table 9. Coefficients ${ }^{\mathrm{a}}$ of Multiple Regression

\begin{tabular}{|c|c|c|c|c|c|c|}
\hline \multirow{2}{*}{\multicolumn{2}{|c|}{ Model }} & \multicolumn{2}{|c|}{$\begin{array}{c}\text { Unstandardized } \\
\text { Coefficients }\end{array}$} & \multirow{2}{*}{$\begin{array}{c}\begin{array}{c}\text { Standardized } \\
\text { Coefficients }\end{array} \\
\text { Beta }\end{array}$} & \multirow[t]{2}{*}{$\mathrm{t}$} & \multirow[t]{2}{*}{ Sig. } \\
\hline & & $\mathrm{B}$ & Std. Error & & & \\
\hline \multirow[t]{4}{*}{1} & (Constant) & .059 & .147 & & .404 & .687 \\
\hline & Successor selection and training & .252 & .067 & .278 & 3.745 & .000 \\
\hline & Post-succession business strategy & .226 & .047 & .237 & 4.851 & .000 \\
\hline & $\begin{array}{l}\text { Post-succession role of } \\
\text { incumbent }\end{array}$ & .316 & .053 & .353 & 5.996 & .000 \\
\hline
\end{tabular}




\begin{tabular}{|c|c|c|c|c|c|}
\hline \multirow[t]{2}{*}{ Model } & \multicolumn{2}{|c|}{$\begin{array}{c}\text { Unstandardized } \\
\text { Coefficients }\end{array}$} & \multirow{2}{*}{$\begin{array}{c}\begin{array}{c}\text { Standardized } \\
\text { Coefficients }\end{array} \\
\text { Beta }\end{array}$} & \multirow[t]{2}{*}{$\mathrm{t}$} & \multirow[t]{2}{*}{ Sig. } \\
\hline & $\mathrm{B}$ & Std. Error & & & \\
\hline $\begin{array}{l}\text { Dissemination of the succession } \\
\text { decision } \\
\text { a. Dependent Variable: Product and S }\end{array}$ & .183 & .048 & .205 & 3.808 & .000 \\
\hline
\end{tabular}

\section{Discussion and Conclusion}

As a result of the formation of more and more family businesses in Yemen, the market has become saturated with different products that confuse end-users. In view of the strong competition that businesses encounter in their efforts to enhance business performance and meet consumers' needs, it is imperative that organizations develop their products and services through innovation and creativity.

This study examined the impact that the main dimensions of succession planning have on product and service innovation in family businesses in Yemen. The findings reveal that succession planning through successor selection and training, post-succession business strategy, post-succession role of incumbent, and dissemination of the succession decision has an impact on product and service innovation in family businesses in Yemen. Successor selection and training has the most influential impact on product and service innovation.

According to the results, succession planning as an independent variable has a strong and significant impact on product and service innovation. This finding supports Hypothesis H1. This result is entirely consistent with Hacibayramoğlu (2014), who concluded that succession planning has a positive impact on family businesses. The results of the study by Adegboyega (2012) revealed that the adoption of innovation and creativity in family businesses led to the creation of a distinctive product that allows businesses to gain a competitive advantage in their industries.

The result of the regression analysis revealed that the dimension of successor selection and training has a significant impact on product and service innovation, which supports Hypothesis H1a. This result is consistent with Le Breton-Miller, Miller and Steier (2004) and Cabrera-Suarez (2005) who argued that the development of a positive orientation relationship between the incumbent and his successor as a training tool is likely to affect innovation, foster the development of the successor's leadership ability, and contribute to the success of the succession within the context of the family businesses.

The result of the analysis revealed that the post-succession business strategy has an impact on product and service innovation and, thus, supports hypothesis H1b. This result is consistent with some previous studies. Sharma et al., (2003) found that family businesses pay a relatively high level of attention to the post-succession work strategy. Funk (2014) stated that the existence of a specific plan to guide the successor during the post-successor period should include consideration of how that individual strengthens aspects of communication with key stakeholders.

The result of the analysis showed that the post-succession role of the incumbent has an impact on product and service innovation, which supports the third sub-hypothesis H1c. The results of this study is inline with Zahrani, Nikmaram and Latifi (2014) who explained that the trusted family member who leads the succession planning strategy has the greatest impact on the success and development of the succession planning process and its effectiveness is keeping the family business active.

Finally, the results of analysis revealed that the dissemination of the succession decision has an impact on product and service innovation and this finding supports the hypothesis H1d. According to Sharma et al., (2003) of all aspects of succession planning, it is the succession decision that is most commonly important. They found that clearly communicating and justifying the succession decision has an impact on the company's performance. As a result, this element could a positively influences the degree of product and service innovation because the announcement of the succession decision plays an important role in legitimizing the chosen successor.

\section{Recommendations}

In view of the theoretical framework of the study, the results confirm that succession planning has an impact on innovation in family businesses. Accordingly, recommendations were provided as follows:

- There is a need for strong and vested plans for succession in businesses, especially family businesses.

- There is a greater need for family businesses in Yemen to welcome and accept any new innovative ideas or suggestions from either a member of the owner's family or employees.

- Businesses should cooperate with local organizations that specialize in trade, industry, and business and seek advice from the Yemeni Business Club to successfully plan succession. 
- The successor should commence working within the role prior to the official handover. This will enable $\mathrm{him} / \mathrm{her}$ to learn how the company works, get to know more about the company's staff and employees, and learn the role before formally commencing.

- Family businesses should create high levels of communication between family members, high desire to maintain family name and reputation, and a high level of conformance with the key elements of succession planning to ensure the continuity of succession planning and its ongoing success.

- Incumbents should allow successors to manage businesses in ways that are more modern and not to restrict them to old ways and methods that the incumbents have been working on for years, potentially decades.

- Family businesses should build and rely on "family constitution", which is considered as an important document that includes a definition of the basic values, vision, and general objectives of the company. In addition, the family constitution usually includes general policies related to some important aspects of the relationship of family members within the company, including the employment of family members, distribution of shares, and succession management and other matters.

\section{References}

Adegboyega, O.T. (2012). Effects of creativity and innovation on the entrepreneurial performance of family business: A study of selected family businesses in Lagos state. A master's project submitted to the department of business studies, Covenant University, Ota, Ogun state.

Alegre, J., Lapiedra, R., \& Chiva, R. (2006). A measurement scale for product innovation performance. European Journal of Innovation Management, 9(4), 333-346.

Al-Haddabi D., (2014). Corporate Family Governance in Republic of Yemen, Yemeni Business Club.

Anderson, T. (2009). Innovative financing of health care. BMJ: British Medical Journal (Online), 339.

Ansoff, H. I. (1965). Corporate strategy. New York: McGraw-Hill

Bakar, L. J. A., \& Ahmad, H. (2010). Assessing the relationship between firm resources and product innovation performance: A resource-based view. Business Process Management Journal, 16(3), 420-435.

Beaver, G. (2002). Small business, entrepreneurship and enterprise development. Pearson Education.

Beck, L., Janssens, W., Debruyne, M., \& Lommelen, T. (2011). A study of the relationships between generation, market orientation, and innovation in family firms. Family Business Review, 24(3), 252-272.

Bergfeld, M. M. H., \& Weber, F. M. (2011). Dynasties of innovation: Highly performing German family firms and the owners' role for innovation. International Journal of Entrepreneurship and Innovation Management, 13(1), 80-94.

Block, J. H. (2012). R\&D investments in family and founder firms: An agency perspective. Journal of Business Venturing, 27(2), 248-265.

Cabrera-Suarez, K. (2005). Leadership transfer and the successor's development in the family firm. The Leadership Quarterly, 16(1), 71-96.

Calantone, R. J., Vickery, S. K., \& Dröge, C. (1995). Business performance and strategic new product development activities: an empirical investigation. Journal of Product Innovation Management, 12(3), 214223.

Chandler, A. D. (1962). Strategy and structure: Chapters in the history of industrial enterprise. Cambridge: Massachusetts Institute of Technology Press, New York.

Chaochotechuang, P. (2016). Investigating Innovation Strategies of New Product Development: Multiple Case Study of Thai Food and Beverage Manufacturing SMEs (Doctoral dissertation).

Chua, J. H., Chrisman, J. J., \& Sharma, P. (2003). Succession and nonsuccession concerns of family firms and agency relationship with nonfamily managers. Family Business Review, 16(2), 89-107.

Collins, L., \& O'Regan, N. (2011). The evolving field of family business. Journal of Family Business Management, 1(1), 5-13.

Craig, J. B., \& Moores, K. (2006). A 10 year longitudinal investigation of strategy, systems, and environment on innovation in family firms. Family Business Review, 19(1), 1-10.

Davis, P. and P. Harveston. (1999). In the founder's shadow: Conflict in the family firm. Family Business Review 12(4):311-323.

De Alwis, A. (2016). Incumbents Influence on Family Business Succession Process. European Journal of Business and Management. 8. 
De Jong, J. P., \& Vermeulen, P. A. (2006). Determinants of product innovation in small firms: A comparison across industries. International small business journal, 24(6), 587-609.

De Massis, A., Frattini, F., \& Lichtenthaler, U. (2013). Research on technological innovation in family firms: Present debates and future directions. Family Business Review, 26(1), 10-31.

Dyck, B., Mauws, M., Starke, F. A., \& Mischke, G. A. (2002). Passing the baton: The importance of sequence, timing, technique and communication in executive succession. Journal of business venturing, 17(2), 143162.

Esuha, J. \& Fletcher D. (2000). The _invisible middle': a critical review of small business development and the political-institutional environment in Kenya. $25^{\text {th }}$ ISBA National Small Firms Conference: Competing Perspectives of Small Business and Entrepreneurship.

Funk, J. (2014). Do family businesses "pay it forward"? seeking to understand the relationship between intergenerational behaviour and environmentally sustainable business practices.

Ganzaroli, A., Fiscato, G., \& Pilotti, L. (2006). Does business succession enhance firms' innovation capacity. Results from an Exploratory Analysis in Italian SMEs, Departmental Working Papers, 29, 200629.

Gersick, K. E. (1997). Generation to generation: Life cycles of the family business. Harvard Business Press.

Grundström, C., Öberg, C., \& Rönnbäck, A. Ö. (2012). Family-owned manufacturing SMEs and innovativeness: A comparison between within-family successions and external takeovers. Journal of family business strategy, 3(3), 162-173.

Hacibayramoğlu, M. G. (2014). The Impact of Succession on Family Business Innovation: A Case Study on Machinery Manufacturing Sector in Ankara (Doctoral dissertation, Middle East Technical University).

Hamel, G. (1998), Strategy innovation, Executive Excellence, Vol. 15 No. 8, pp. 7-8.

Han, J. K., Kim, N., \& Srivastava, R. K. (1998). Market orientation and organizational performance: is innovation a missing link?. The Journal of marketing, 30-45.

Harris, R. G., \& Mowery, D. C. (1990). Strategies for innovation: An overview. California Management Review, 32(3), 7-16.

Heck, R. K., Hoy, F., Poutziouris, P. Z., \& Steier, L. P. (2008). Emerging paths of family entrepreneurship research. Journal of Small Business Management, 46(3), 317-330.

Karanja, J. G. (2012). Role of succession planning on survival of small and medium family enterprises after retirement/death of the first generation entrepreneurs in Kenya. Prime Journal of Business administration and Management (BAM), 2(12), 788-802.

Kellermanns, F. W., Eddleston, K. A., Barnett, T., \& Pearson, A. (2008). An exploratory study of family member characteristics and involvement: Effects on entrepreneurial behavior in the family firm. Family Business Review, 21(1), 1-14.

Kelly, L. M., Athanassiou, N., \& Crittenden, W. F. (2000). Founder centrality and strategic behavior in the familyowned firm. Entrepreneurship Theory and Practice, 25(2), 27-42.

Krejcie, R. V., \& Morgan, D. W. (1970). Determining sample size for research activities. Educational and psychological measurement, 30(3), 607-610.

Le Breton, Miller, I. L., Miller, D., \& Steier, L. P. (2004). Toward an integrative model of effective FOB succession. Entrepreneurship theory and practice, 28(4), 305-328.

Leibman, M., Bruer, R. A., \& Maki, B. R. (1996). Succession management: The next generation of succession planning. People and Strategy, 19(3), 16.

Melo, Paul (2011). Innovation and firm's interaction behaviour: Is innovation associated with local or non-local interactions? An investigation of clustered micro and small technology-based firms in Brazil. $\mathrm{PhD}$ thesis, Waterford Institute of Technology.

Meneses, R., Coutinho, R., \& Carlos Pinho, J. (2014). The impact of succession on family business internationalisation: The successors' perspective. Journal of Family Business Management, 4(1), 24-45.

Miles, R. E., \& Snow, C. C. (1978). Organizational strategy, structure and process. New York: West.

Morris, M. H., Williams, R. O., Allen, J. A., \& Avila, R. A. (1997). Correlates of success in family business transitions. Journal of business venturing, 12(5), 385-401.

Nyalita, A. M. (2015). Succession planning, entrepreneurial orientation, business development services and performance of small and medium family businesses in Machakos County, Kenya. (Unpublished PhD thesis). University of Nairobi, Kenya.

Poza, E. (2010). Family Business ( $3^{r d}$ Ed). Ohio: South-Western Cengage Learning

Rajapathirana, R. J., \& Hui, Y. (2017). Relationship between innovation capability, innovation type, and firm performance. Journal of Innovation \& Knowledge. 
Rioux, S. M., \& Bernthal, P. (1999). Recruitment and selection practices survey report (Vol. 2). Development Dimensions International.

Roberts, P. W., \& Amit, R. (2003). The dynamics of innovative activity and competitive advantage: The case of Australian retail banking, 1981 to 1995. Organization science, 14(2), 107-122.

Roberts, R. (1998), Managing innovation: the pursuit of competitive advantage and the design of innovationintense environments, Research Policy, Vol. 27, pp. 159-75.

Rogers, E.M. (1998). The Definition and Measurement of Innovation, Melbourne Institute of Applied Economic and Social Research (Working Paper), Parkville, Victoria.

Rothwell, W. J. (2010). Effective succession planning: Ensuring leadership continuity and building talent from within. AMACOM Div American Mgmt Assn.

Schumpeter, J.A. (1934). The Theory of Economic Development: An Inquiry into Profits, Capital and the Business Cycle, Harvard University Press, Boston, MA.

Sharma, P., Chrisman, J. J., \& Chua, J. H. (1997). Strategic management of the family business: Past research and future challenges. Family business review, 10(1), 1-35.

Sharma, P., Chrisman, J. J., \& Chua, J. H. (2003). Succession planning as planned behavior: Some empirical results. Family Business Review, 16(1), 1-15.

Sharma, P., Chrisman, J. J., Pablo, A. L., \& Chua, J. H. (2001). Determinants of initial satisfaction with the succession process in family firms: A conceptual model. Entrepreneurship Theory and Practice, 25(3), 1736.

Sharma, R., Yetton, P., \& Crawford, J. (2009). Estimating the effect of common method variance: The methodMethod pair technique with an Illustration from TAM Research. Mis Quarterly, 473-490.

Shepherd, D. A., \& Zacharakis, A. (2000). Structuring family business succession: An analysis of the future leader's decision making. Entrepreneurship Theory and Practice, 24(4), 25-39.

Škerlavaj, M., Song, J. H., \& Lee, Y. (2010). Organizational learning culture, innovative culture and innovations in South Korean firms. Expert systems with applications, 37(9), 6390-6403.

Stalk, G., \& Foley, H. (2012). Avoiding the traps that can destroy family businesses. Harvard Business Review.

Van der Merwe, S. P. (2010). An assessment of the determinants of successor development in family businesses. Acta Commercii, 10(1), 120-136.

Venter, E., Boshoff, C., \& Maas, G. (2005). The influence of successor-related factors on the succession process in small and medium-sized family businesses. Family Business Review, 18(4), 283-303.

Ward, J.L. (1987). Keeping the family business healthy: How to plan for continuing growth, profitability, and family leadership. San Francisco: Jossey-Bass.

Wood, S. (1999). Family-friendly management: testing the various perspectives. National Institute Economic Review, 168(1), 99-116.

Yemeni Business Club. (2010). Corporate Governance Guide in Yemen. Sana'a, Yemen.

Zahra, S. A., \& Das, S. R. (1993). Innovation strategy and financial performance in manufacturing companies: An empirical study. Production and operations management, 2(1), 15-37.

Zahrani, M. A., \& Nikmaram, S. (2014). Impact of family business characteristics on succession planning: A case study in Tehran industrial towns. Iranian Journal of Management Studies, 7(2), 229.

\section{Copyrights}

Copyright for this article is retained by the author(s), with first publication rights granted to the journal. This is an open-access article distributed under the terms and conditions of the Creative Commons Attribution license (https://creativecommons.org/licenses/by-sa/4.0/). 